\title{
The Role of Professional Culture of Future Employees of The Penal System
}

\author{
Yuri Yuryevich Tishchenko ${ }^{1}$, and Elena Pavlovna Radchenko ${ }^{1 *}$ \\ ${ }^{1}$ Federal State Research Institute of the Federal Penitentiary Service of the Russian Federation, \\ 125130, Moscow, Russian Federation
}

\begin{abstract}
The purpose of this research is to form a professional culture of future specialists of the penal system and a set of pedagogical conditions, contributing to its function. The main issues addressed in the study were aimed at identifying the following: what should be understood by the professional culture of future specialists in the penal system and what is necessary for the formation of a professional culture among cadets. The appliance of the integrated use of statistical and mathematical methods, methods of comparative analysis, interviewing, and components of innovative educational technologies aimed at obtaining maximum results of professional training in the process of forming competencies allowed obtaining certain results. The study revealed that the integrated use of all the components of professional culture in the educational process facilitates the adaptation of students to the educational environment, motivates their interest in educational and cognitive activities, stimulates personal development and intellectual activity, contributes to the formation of competencies that future criminal employees should have the executive system.
\end{abstract}

\section{Introduction}

It is necessary to pay close attention to one of the main problems for the effective training of future employees of the penitentiary system of the Russian Federation - this is what regulates public relations, helps people better understand each other, accumulates experience, regulates human relations and worldview - this is culture.

The relevance of this problem lies in the fact that the specifics of the penitentiary system imposes on cadets the performance of certain tasks, which determine the main directions of the formation of trainees' professional culture. The peculiarity of the conditions of the activity of the penitentiary system employees is also related to the fact that they have to constantly deal with persons associated with criminal activity.

It is necessary to focus on the development of spiritual, moral, and cultural values in the process of training. One of the key prerequisites for achieving the rule of law in society, reducing social tension becomes the professional culture of specialists in the penal system.

The purpose of the research is to form a professional culture of future specialists of the penal system and a set of pedagogical conditions conducive to its functioning.

* Corresponding author: helenr2003@mail.ru 
In the process of work, it is necessary to solve several tasks on the formation of the professional culture of future employees of the penal system: formation and development of a professional culture of future employees specialists of the penitentiary system; realization of a complex of pedagogical conditions; development of a structural-professional model for training of employees of the penitentiary system.

The theoretical basis of this study was composed by the following authors: A.P. Panfilova [1], V.V. Kraevsky [2], F. Isaev, V.A. Slastenin, E.N. Shiyanov [3], V.P. Bespalko, S.A. Slastenin, M.V. Plaskina, G.K. Selevko, B.T. Likhachev [4-8], as well as V.P. Bespalko [9].V. It is possible to distinguish the following foreign researchers: Yee Fai Nga, Kwan Kit Chanb, Huey Leic, Phoebe Mokc, Shing, etc. [10], Kevin M. W. [11], Frida Pemer, Jost Sieweke, and Andreas Werr [12], Juan Meng and Bruce K. Berger [13].

A.P. Panfilova rightly notes that the system of the traditional training of specialists today does not fully satisfy the needs of the practice and requires transition into an innovative cycle of development [1]. Researchers in the field of the professional culture of a specialist consider this concept from different aspects of social life. V. V. Kraevsky believes that professional culture acts as a prerequisite for the formation of professionalism of an employee [2], I.F. Isaev, V.A. Slastenin, E.N. Shiyanov believe that this is an indicator of a person's professional readiness [3]. Nevertheless, the formation of a professional culture of future employees of the penitentiary system is directly related to pedagogical technologies, which are the basis of the organizational and methodological structure of the educational process. This issue is being investigated by several domestic scientists - V.P. Bespalko, S.A. Slastenin, M.V. Plaskina, G.K. Selevko, B.T. Likhachev et al. [4-8]. With all the variety of approaches to the definition of this concept, B.T. Likhachev believes that pedagogical technology is an organizational and methodological toolkit of the educational process [8], and V.P. Bespalko - an informative technique for the implementation of the educational process [9].

Following G.K. Selevko we use a subject approach to the concept of "pedagogical technology" [7], according to which we understand the totality of methods and means of implementing a specific content of training within a single academic subject, as well as a description of the teacher's activities under the pedagogical teaching technology [14]. This approach to understanding the essence of pedagogical technology is supported by other scientists [15]. However, it should be remembered that the elements of pedagogical technology should not only be reproduced by any teacher but also guarantee the achievement of the planned results of the federal state standard of higher education.

\section{Methods}

In the process of work, focusing on the research of the above scholars, it was necessary to solve several problems in shaping the professional culture of future employees of the penitentiary system: what should be understood as the professional culture of future specialists of the penitentiary system and what is necessary for the formation of professional culture in this system.

At the same time, traditional educational technologies, although not among the modern methods of teaching, are still widely used in the practice of organizing educational activities $[16,17]$. Such a construction of the educational process is conditionally oriented towards the recognition and reproductive reproduction of previously acquired information. At the same time, other levels of the process of assimilation of knowledge associated with the student's independent actions to acquire new knowledge, the formation of professional culture, the creative application of the information received in practical conditions, remained beyond the attention of participants in the educational process $[18,19]$. Changing priorities in the field of higher education has necessitated the formation of the legal and moral components of the professional culture of specialists in the penal system. 
In 2017, a study was conducted based on several higher educational institutions of the penal system of the Russian Federation, in which 215 people participated, divided into three groups - two experimental and one control. The variative type of experiment was chosen as the basis. Different conditions for the provision of pedagogical services were created to determine the role of the professional culture of students studying the penitentiary system in the experimental groups. The cadets of the control group continued their training according to the standard program. The experiment has been lasted for three months, in several stages, one month was allocated for each stage.

The first stage was to build a logical chain of polls and develop a methodology for the work of experimental groups; at the second stage, an experiment was conducted to form a professional culture for students in the penitentiary system. The second stage of the experiment took place, according to the formed model of the pedagogical proposal of the studied material. In some disciplines, deviations from the standard professional program were made for all experimental groups and new methodical programs and software were offered with follow-up control of the educational process with a bias towards the formation of a professional culture. In the course of work, an adjustment was made to the training of future employees of the penal system. The third phase was the final one, analyzing the findings and a restudy was carried out on the control group. At each stage, tasks and methods of solving them were defined.

Based on mathematical and comparative analysis, the material has been collected and analyzed for three months, which allowed creating graphs and tables showing the stages of development and formation of the professional culture of students in terms of the selected elements: professional orientation, professional competence, professional qualities [20-22]. During the experiment, the subjects themselves came to understand professional selfdetermination with the help of the diagnostic technique offered by them. When conducting control works in all groups, the influence on the results of the study of the factor of natural development was excluded.

\section{Results}

The basis for the formation of the professional culture of future employees of the penitentiary system was such criteria as interest in work, responsiveness, value orientations, knowledge, skills, professional competence, exactingness, attentiveness, ability to interact with people. All this should be part of the training program for legal professionals with humane values, professional knowledge, able to work in difficult circumstances. In our study, we consider professional culture to be a comprehensive characteristic that includes appropriate professional orientation, competence, and professionally important personal quality cadet. For a more accurate answer to this question, an interview was conducted among the population and cadets, the results of which are presented in Table 1.

Table 1. Criteria for evaluation of future specialists in the penal system, including elements of professional culture (on a 5-point scale)

\begin{tabular}{|l|l|l|l|}
\hline № & Criterion & Cadet assessment & Population assessment \\
\hline 1 & Work interest & 5 & 5 \\
\hline 2 & Responsiveness & 5 & 5 \\
\hline 3 & Values-based orientations & 4 & 5 \\
\hline 4 & Perception & 3 & 5 \\
\hline 5 & Skills & 4 & 5 \\
\hline 6 & Professional competence & 3 & 5 \\
\hline 7 & Exactingness & 3 & 5 \\
\hline 8 & Mindfulness & 3 & 5 \\
\hline 9 & Ability to interact with people & 3 & 5 \\
\hline
\end{tabular}


Based on the obtained data, we conclude that the population places high demands on the elements of the professional culture of future employees of the penitentiary system, which leads to a lack of understanding in society. The teaching staff forms a task for themselves in improving the professional image of future employees of the penitentiary system by forming a professional culture in the latter.

To determine the role of professional culture under different conditions, we have been analyzing such components of professional culture as professional orientation, professional competence, professional qualities of the future penitentiary system employee for three months. Following the analysis and processing of the information, we obtained the results presented in Table 2.

Table 2. The role of professional culture according to its components

\begin{tabular}{|l|l|l|l|l|l|l|l|l|l|}
\hline \multirow{2}{*}{ Groups } & \multicolumn{9}{|l|}{ Components of professional culture } \\
\cline { 2 - 10 } & $\begin{array}{l}\text { Professional direction } \\
\begin{array}{l}\text { Before } \\
\text { the } \\
\text { experi } \\
\text { ment }\end{array}\end{array}$ & $\begin{array}{l}\text { Experi } \\
\text { ment } \\
\text { period }\end{array}$ & $\begin{array}{l}\text { After } \\
\text { the } \\
\text { experi } \\
\text { ment }\end{array}$ & $\begin{array}{l}\text { Pefore } \\
\text { the } \\
\text { experi } \\
\text { ment }\end{array}$ & $\begin{array}{l}\text { Experi } \\
\text { ment } \\
\text { period }\end{array}$ & $\begin{array}{l}\text { After } \\
\text { the } \\
\text { experi } \\
\text { ment }\end{array}$ & $\begin{array}{l}\text { Before } \\
\text { the } \\
\text { experi } \\
\text { ment }\end{array}$ & $\begin{array}{l}\text { Experi } \\
\text { ment } \\
\text { period }\end{array}$ & $\begin{array}{l}\text { After } \\
\text { the } \\
\text { experi } \\
\text { ment }\end{array}$ \\
\hline Control & 3.79 & 3.86 & 3.89 & 3.54 & 3.79 & 3.42 & 3.55 & 3.79 & 3.89 \\
\hline $\begin{array}{l}1 \text { st } \\
\text { experi } \\
\text { mental } \\
\text { group }\end{array}$ & 3.76 & 4.30 & 4.87 & 3.52 & 4.25 & 4.65 & 3.74 & 4.19 & 4.76 \\
\hline $\begin{array}{l}\text { 2nd } \\
\text { experi } \\
\text { mental } \\
\text { group }\end{array}$ & 3.82 & 4.111 & 4.60 & 3.50 & 3.90 & 3.93 & 3.73 & 3.80 & 4.04 \\
\hline
\end{tabular}

As a result of the analysis, it can be concluded that the highest indicators were identified in the 2nd experimental group, in which all necessary criteria and pedagogical conditions were mastered. The development of the components of professional culture in the control group was insignificant, as systematic and focused work was not carried out.

Thus, as a result of the study, it was determined that a systematic approach to the education of a cadet as an individual, with a certain set of knowledge, skills, experience, and values in the field of criminal executive activity, aimed at solving official tasks and ensuring human rights, protecting the health of prisoners, the involvement of convicts in labor, as well as the provision of their general and professional education and vocational training following the principles of humanism, legality, and justice, can be understood as the professional culture of future specialists of the penal system.

It is advisable to prepare and develop a set of pedagogical conditions for training with the subsequent implementation together with the structural and functional model of the formation of professional culture in educational institutions of the penal system in preparing future specialists for the formation of professional culture in the penal system

\section{Conclusion}

Thus, it can be noted in the analysis of theoretical and practical material that there are certain difficulties in the formation of professional culture in educational institutions in the preparation of employees of the penal system. To correct this situation, it is necessary to determine the choice of a set of tools and methods, as well as a set of theoretical and 
methodological approaches that would ensure the formation of sufficient professional competencies.

\section{References}

1. A.P. Panfilova, Educational technologies 4, 40-45 (2014)

2. V.V. Kraevsky, General principles of pedagogy (Publishing Center "Academy", Moscow, 2005)

3. V.A. Slastenin, I.F. Isaev, E.N. Shiyanov, Pedagogy Textbook for students of higher ped. institutions (Publishing Center "Academy", Moscow, 2002)

4. V.P. Bespalko, Components of educational technology (Pedagogy, Moscow, 1989)

5. V.A. Slastenin, Pedagogy (School-Press, Moscow, 1997)

6. M.V. Plaskina, The concept of "learning technology" in modern pedagogy, Pedagogy: traditions and innovations: materials of the V International Scientific Conference, Chelyabinsk, Russia (2014)

7. G.K. Selevko, Modern educational technology: a manual for university students (Public education, Moscow, 1998).

8. B.G. Likhachev, Pedagogy (Prometey, Moscow, 1992)

9. V.P. Bespalko, Components of educational technology (Pedagogy, Moscow, 1989)

10. Y.F. Nga, K.K. Chanb, H. Leic, P. Mokc, S.Y. Leungd, The European Journal of Social and Behavioural Sciences EJSBS, XXVI 2, 2910-2926 (2019)

11. M.W. Kevin, The European Journal of Social and Behavioural Sciences EJSBS, XXV 5, 2948-2976 (2019)

12. F. Pemer, J. Sieweke, A. Werr, Journal of Purchasing and Supply Management 24(4), 314-320 (2018)

13. J. Meng, B.K. Berger, Public Relations Review 45(1), 64-75 (2019)

14. S.I. Girko, International Journal of Civil Engineering and Technology 9(10), 1582-1593 (2018)

15. A.G. Asmolov, Psychology in Russia: State of the art 6(1), 3-20 (2013)

16. Y.I. Kurichenko, Business. Education. Right 2(47), 450-454 (2019)

17. E.V. Pavlova, Degree of preparedness of cadets of final courses of educational institutions of higher education of penitentiary system of Russia to service, Analytical review (2016)

18. Z. Velkovski, E. Rizova, International Journal of Cognitive Research in Science, Engineering and Education 3(1), 81-88 (2015)

19. V.V. Mechnikov, Features of the state law enforcement service in the internal Affairs bodies (for example, units of the Department for combating organized crime and terrorism): abstract. dis. ... legal sciences (Moscow, 2006)

20. V.V. Kapralov, Yaroslavl pedagogical Bulletin 2(3), 140-148 (2014)

21. A.N. Sivak, Yu.M. Perevozkina, I.A. Fedoseeva, Prospects of science and education 2(38), 385-398 (2019)

22. M. Kozin, G. Pyrchenkova, E. Radchenko, The role of public-private partnership in ensuring the economic security of the state, in Innovative Technologies in Environmental Science and Education ITESE-2019 E3S Web of Conferences 135 (2019) 